which was published by the Geological Society in 1895, and led to an interminable controversy.

Newton's most fundamental contributions to science, however, were made in three memoirs, published in the Philosophical Transactions of the Royal Society. In 1887 he gave the first satisfactory description of the brain of a pterodactyl, based on a specimen which he had obtained from the Upper Lias of Whitby. In 1893 and 1894 he described a series of reptiles from the Permo-Triassic sandstones of Elgin, Scotland, revealing for the first time in Europe genera related to the primitive reptiles already known in the Karroo formation of South Africa. By a most ingenious method of taking impressions from hollows left by the decay of the bones once buried in the sandstones, he reconstructed various parts of the skulls and skeletons, and added greatly to our knowledge of the groups they represented.

While engaged in his official duties and research, Newton found time to take an active part in the work of the London scientific societies, and he was a familiar figure at the meetings. At various times he was a member of Council of the Geological Society and Geologists' Association, and of the Publication and Finance Committees of the Zoological Society. He was elected a Fellow of the Royal Society in 1893, and received the Lyell Medal from the Geological Society in the same year. $\mathrm{He}$ was President of the Geologists' Association in 1896-8, and President of the Palaeontographical Society from 1921 to 1928 . He ceased regular association with his scientific colleagues only when the feebleness of advancing years prevented his going far from home, and his absence left a regretted blank.

\title{
CORRESPONDENCE.
}

\section{A QUESTION OF NOMENCLATURE.}

SIR,-For facility of description and discussion, a name is needed for the ancient Volcanic Series of the country between the Menai Strait and Snowdonia, a region known for centuries as "Arvon" because it faces Anglesey (Von $=$ Mon=Anglesey). The series comprises the well-known rhyolite of Llyn Padarn, the rhyolite between Bangor and Carnarvon, and the pyroclastic rocks of Bangor itself. Moreover, in the course of mapping, I have found that it is a good deal more extensive, various members occurring at places where they have not hitherto been recognized. The formation is of great importance in the early volcanic history of Britain.

But, as is well-known, its age has been a matter of serious controversy ; Geikie, Blake, and others holding it to be Lower Cambrian; Hughes, Bonney, and others holding it to be Pre-Cambrian. My own duty in the matter is to reserve judgment until my mapping is completed, as several perplexities remain. Perhaps, however, 
I may venture so far as to say that a Pre-Cambrian age now seems highly probable. Nevertheless, in view of possible error, the name adopted should be free from chronological assumptions. Yet even if the series be Pre-Cambrian, that term alone is insufficient, since it is certainly (Greenly, Q.J.G.S., 1923, pp. 334-5) far later than the Mona Complex. We need some such term as Uriconian or Pebidian, though it may be long before we can correlate with those formations.

The familiar local place-names do not lend themselves to our purpose. "Bangorian" is ponderous ; "Dinorwiggian" tends to evoke a smile. "Segontian," suggested to me by Mr. Cantrill, is euphonious, and appropriate because Segontium was the Roman Castrum-in-Arvon (= Car-n-arvon). True : an objection can be raised that Segontium itself stands on Ordovician rocks. But Professor Lloyd, the historian of Wales, tells me that the Roman fort must have been named after the river, and the river does traverse several miles of the rocks we are considering.

But the ideal name is, obviously, "Arvonian". Hicks, indeed, when introducing that term (Q.J.G.S., 1879, p. 287) did actually apply it to this very series. Unfortunately, he also applied it to certain rocks at St. Davids which turned out not to be a "formation" at all, and as Mr. Green remarks, "the term was dropped by general consent." It seems hard, however, that by reason of an error of half-a-century ago which, after all, was an error in South Wales, not in North Wales, we of to-day should be debarred from the use of so felicitous a term.

I hesitate, nevertheless, to revive it without having ascertained that it will command the general assent of workers on the ancient rocks of Britain. Accordingly, the purpose of this letter is to elicit comment. Not that complete unanimity is necessary. "Ordovician," for example, did not command unanimity for a good many years. But I do wish to know whether there would be serious and widespread disapproval. So I propose to act as follows.

(1) In the event of serious disapprobation, I will fall back upon "Segontian".

(2) Unless someone devise some term which is better than either.

(3) If serious disapproval be not manifested, then I will adopt "Arvonian". And I hope that such will be the case.

I will ask all those who have any decided feeling on the matter, on one side or the other, to make it known, and to do so within a few weeks at latest, so that I may be able, in some two or three months, to arrive at a decision which there will be no need to reverse.

EDWard Greenty.

[The Editor regrets that owing to the very large number of original papers now in hand, he cannot undertake to publish correspondence on this subject: letters should be sent to Dr. Greenly, at Aethwy Ridge, Bangor, Carnarvonshire.] 